\title{
KEPERCAYAAN MEREK DAN BRAND AFFECT SEBAGAI ANTESEDEN DARI LOYALITAS MEREK
}

\author{
Sri Rahayu \\ Mahasiswa Program Doktor Ilmu Ekonomi (PDIE), Universitas Sebelas Maret Surakarta \\ Email: rahayu_ms@yahoo.com \\ Mugi Harsono \\ Universitas Sebelas Maret Surakarta \\ Email: mugihs@uns.ac.id
}

\begin{abstract}
The purpose of this paper is to explain the important role of brand and brand loyalty in marketing activities. This paper also explains the antecedents of brand loyalty. The role of a brand does not only actas a name, but also increasing the company's competitive advantage. The benefits of a brand for consumers are, among many others, for emotional, self and social expression, attitudes, values and culture benefits. In the mean time, the role of brand loyalty in marketing is to contribute to the survival of the company, to increase new customer opportunities as well as to reduce marketing costs. To improve a brand loyalty, a companyshould increase its brand trust in advance as it plays an important role in improving brand loyalty. A cpmpany brand trust has two dimensions of intention and reliability. Brand affect, on the other hand, is an important for improving a brand loyalty. Therefore, a company'sbrand trust and brand affect should be improved for the brand loyalty to improve as well.
\end{abstract}

Key words : Brand trust, Brand Affect, Brand Loyalty

\begin{abstract}
Abstrak
Tujuan makalah ini adalah untuk menjelaskan mengenai peran pentingmerek dan loyalitas merek dalam aktifitas pemasaran. Tujuan lainnya untuk menjelaskan anteseden dari loyalitas merek. Merek tidak hanya berperan sebagai nama, namun lebih dari itu dapat meningkatkan keunggulan kompetitif perusahaan. Sedangkan manfaat merek bagi konsumen adalah manfaatemosional, ekspresidiridan social, atibut, nilai dan kebudayaan. Peran loyalitas dalam pemasaran adalah mampu berkontribusi bagi kelangsunganhidupperusahaan, membukapeluangpelangganbarudandapatmengurangibiayapemasaran. Untuk meningkatkan loyalitas merek, harus meningkatkan kepercayaan merek terlebih dahulu. Karena kepercayaan merek memaninkan peran penting dalam upaya meningkatkan loyalitas merek.Kepercayaan merek memiliki dua dimensi yaitu intention dan reliabilitydari sebuah merek. Brand affect, merupakan faktor penting yang sangat dibutuhkan dalam meningkatkan loyalitas merek. Oleh karena itu,dalam meningkatkan loyalitas merek, sebuah perusahaan harus meningkatkan kepercayaan dan brand affect.
\end{abstract}

Kata Kunci: kepercayaan merek, pengaruh merek, loyalitas merek

\section{PENDAHULUAN}

Dewasa ini persaingan usaha dibidang industri barang maupun jasa semakin kompetitif. Adanya persaingan tersebut memaksa setiap perusahaan berupaya mencari strategi yang tepat untuk mempertahankan kelangsungan hidup perusahaan dan memenangkan persaingan. Upaya yang dapat dilakukan oleh perusahaan adalah mempertahankan pelanggan melalui merek.Merek adalah nama, istilah, tanda, simbol, desain atau kombinasi dari semuanya yang berguna untuk mengidentifikasi produk para penjual dan membedakan dari produk pesaing (Lamb, 2001). 
Peranan merek bukan lagi sekedar nama ataupun pembeda dari merek pesaing, lebih dari itu, merek sudah menjadi faktor penentu keunggulan bersaing. Aaker (1997) menjelaskan bahwa sebuah merek bisa memiliki posisi yang sangat kuat dalam menjaga loyalitas konsumen.

Menjaga loyalitas ini menjadi alasan penting bagi sebuah perusahaan untuk mengelola dan mengembangkan merek agar lebih bermakna daripada sekedar produk. Produk hanya menjelaskan atribut dimensinya yang akan dipertukarkan dan mudah ditiru oleh perusahaan lain, sedangkan merek dapat menjelaskan emosi serta hubungan secara spesifik dengan pelanggan serta sifatnya tidak berwujud (intangible) sehingga tidak mudah ditiru oleh pesaing. Merek berusaha untuk selalu menumbuhkan loyalitas. Menurut Rangkuti (2004) apabila para konsumen beranggapan bahwa merek tertentu secara fisik berbeda dari merek pesaing, citra merek tersebut akan melekat secara terus-menerus sehingga dapat membentuk kesetiaan terhadap merek tertentu yang pada akhirnya akan menciptakan loyalitas pelanggan.

Merek suatu produk atau jasa dianggap memiliki jiwa, sehingga dapat dipandang sebagai suatu organisasi, orang, atau simbol yang berfungsi sebagai alat untuk membedakan antara produk yang satu dengan produk lainnya (Halim, 2006; Chauduri \& Holbrook, 2001). Pendapat lainya menganggap bahwa merek memiliki kekuatan yang bermanfaat bagi perusahaan antara lain; dapat mengurangi kerentanan terhadap pasar yang kompetitif, memberikan marjin yang lebih besar, membantu hubungan kerjasama dengan perusahaan lain dan menciptakan peluang untuk memperluas merek (Delgado\& Manuera, 2004). Dari penjelasan tersebut, diketahui bahwa merek merupakan sesuatu yang sangat penting bagi suatu perusahaan dalam menjalankan aktivitas pemasaran produk dan jasa.

Dalam literatur manajemen pemasaran, loyalitas merek atau brand loyalty dianggap sebagai sebuah konsep yang sangat penting. Hal ini dikarenakan brand loyalty merupakan inti dari setiap nilai merek. Pada saat inti dari setiap nilai merek tersebut didapatkan dan dipertahankan, loyalitas terhadap sebuah produk barang atau jasa akan bertahan lama. Hal tersebut menyebabkan pelanggan enggan untuk berpindah ke merek lain dan akan memberikan keuntungan bagi merek perusahaan (Aaker, 1997; Baldinger \& Rubinson, 1996; Chaudhuri, 1999). Oleh karena itu, suatu perusahaan harus mampu membangun dan mempertahankan loyalitas merek agar dapat menjaga keberlangsungan hidup perusahaan.

Beberapa penelitian terdahulu telah banyak membahas mengenai peran kepercayaan merek, brand affect, dan kepuasan merek dalam meningkatkan loyalitas merek. Seperti penelitian yang dilakukan oleh Kuo (2012) Brand affect dapat berperan dalam meningkatkan loyalitas merek (Kuo, 2012). Brand affect dan kepercayaan merek berpengaruh positif terhadap loyalitas merek (Anwar, et al., 2011, Ong et al., 2015, Gecti\& Zengin, 2013; Kurt Matzler, 2006).Dari penjelasan tersebut, maka diketahui bahwa loyalitas merek dapat ditingkatkan dengan meningkatkan kepercayaan merek, dan brand affect.

Artikel ini bertujuan untuk menjelaskan peran penting dari variabel loyalitas merek dalam kegiatan pemasaran. Selain itu untuk menjelaskan aktor penentu atau anteseden dari loyalitas merek. Faktor tersebut meliputi kepercayaan merek dan brand affect. Penjelasan tersebut akan disajikan pada bagian pembahasan.

\section{PEMBAHASAN}

\section{Merek}

Merek adalah nama, istilah, tanda, simbol, desain atau kombinasi dari semuanya yang berguna untuk mengidentifikasi produk para penjual dan membedakan dari produk pesaing (Lamb, 2001). Peranan merek bukan lagi sekedar nama ataupun pembeda dari merek pesaing, lebih dari itu, merek sudah menjadi faktor penentu keunggulan bersaing.Selain itu merek merek merupakan sebuah janji dari suatu organisasi kepada pelanggan untuk memberikan manfaat yang ditawarkan oleh merek tersebut. Manfaat yang diberikan tidak hanya manfaat fungsional saja, namun meliputi manfaat emosional, ekspresi diri dan sosial (Aaker, 2015). Lebih jauh merek dianggap sebagai kumpulan dari atribut, manfaat, nilai, dan kebudayaan (Kotler, 2005). Berdasarkan penjelasan tersebut maka dapat diketahui peranan merek tidak hanya sekedar nama atau simbol, namun lebih jauh merek mampu berperan menjadi keunggulan bersaing perusahaan, manfaar emosional, ekspresi diri konsumen, dan manfaat sosial. Selain itu merek juga merupakan atribut, nilai dan 
kebudayaan. Oleh karena itu suatu perusahaan harus berupaya keras untuk menciptakan, memelihara, melindungi dan meningkatkan kualitas merek.

\section{Loyalitas Merek}

Loyalitas merek merupakan konsep yang sangat penting dalam literatur pemasaran. Loyalitas merek dapat memberikan kontribusi dan manfaat penting bagi kelangsungan hidup perusahaan, membuka peluang pelanggan baru dan dapat mengurangi biaya pemasaran. Hal tersebut disebabkan oleh konsumen yang loyal terhadap suatu merek, akan melakukan pembelian secara berulang-ulang, bersedia membayar dengan harga premium, dan merekomendasikan kepada orang lain (Wang, 2007, Chang \& Fong, 2010). Selain dapat mengurangi biaya pemasaran loyalitas konsumen juga akan membuka peluang untuk mendapatkan konsumen baru yang dihasilkan dari rekomendasi dari pelanggan. Sebagaimana diketahui bahwa konsumen akan lebih percaya kepada orang sudah memiliki pengalaman menggunakan suatu merek dibanding dengan iklan atau promosi dari perusahaan.

Loyalitas merek didefinisikan sebagai komitmen yang sangat kuat untuk membeli kembali atau berlanganan pada produk atau jasa yang diinginkan secara konsisten di masa depan, sehingga menyebabkan pembelian merek atau barang yang sama, walaupun ada pengaruh situasional dan upaya pemasaran yang berpotensi menyebabkan perilaku beralih (Oliver, 1999). Definisi tersebut menekankan dua aspek yang berbeda yaitu konsep perilaku (behavioral) dan sikap (attitudinal) (Aaker, 1991; Day 1969; Assael, 1998; Oliver, 1999; Jacoby \& Chesnut, 1978). Loyalitas perilaku atau pembelian (behavioral and purchase) adalah pembelian merek secara berulang - ulang, sedangkan loyalitas sikap merek (attitudinal loyalty) adalah tingkat komitmen terhadap nilai-nilai unik yang terdapat pada merek.

Beberapa penelitian menggunakan istilah loyalitas pembelian (purchase loyalty) dan loyalitas sikap (attitudinal loyalty) (Chauduri \& Holbrook, 2001; Matzler, 2006). Sedangkan Gectic \& Zengin, (2013) menyebut dimensi loyalitas merek dengan istilah behavioral loyalty dan attitudinal loyalty. Seperti telah dijelaskan sebelumnya bahwa antara Behavioral loyalty dan purchase loyalty memiliki makna yang sama, yaitu perilaku konsumen dalam melakukan pembelian secara berulang-ulang.

Pengukuran loyalitas merek harus melibatkan dua dimensi yaitu behavioral dan attitudinal loyalty. Karena loyalitas tidak cukup hanya diukur dari satu sisi saja, misal perilaku pembelian yang berulang-ulang. Namun harus diukur dari loyalitas pembelian dan loyalitas sikap. Pengukuran loyalitas yang hanya menggunakan satu dimensi keperilakuan saja dilakukan oleh beberapa peneliti sebelumnya (Bowen dan Chen, 2001; Lau dan Lee, 1999). Hal tersebut bertentangan dengan pendapat yang menyatakan bahwa mengukur loyalitas merek harus melibatkan kedua dimensinya. Pengukuran loyalitas merek yang dilakukan hanya dari perilaku pembelian saja dianggaptidak mampu menjelaskan loyalitas merek dan menunjukan konsep loyalitas merek sebagai konsep yang masih lemah sehinggamembutuhkan pengembangan lebih lanjut, (Jacoby dan Chesnut, 1978). Aaeker (1991), Oliver (1999) mengembangkan pengukuran yang menekankan dua aspek yang berbeda yaitu konsep perilaku (behavioral) dan sikap (attitudinal).

\section{Kepercayaan Merek}

Kepercayaan merek didefinisikan sebagai ekspektasi keyakinanterhadap kehandalan dan niat dalam situasi yang melibatkan risiko kepada konsumen (Delgado, 2004). Definisi lain dari kepercayaan merek adalah perilaku kerelaan konsumen untuk bergantung pada kemampuan merek yang menggambarkan fungsi produk (Chauduri \& Holbrook, 2001). Melengkapi kedua definisi tersebut Wang (2002) mendefinisikan kepercayaan merek sebagai kesediaan konsumen untuk mengandalkan dan meyakini merek tersebut terkait dengan kehandalan merek, jujur dan altruisme (Wang, 2002). Konsumen, mengembangkan kepercayaan pada merek berdasarkan keyakinan positif mengenai ekspektasi mereka terhadap perilaku organisasi dan kinerja produk yang diwakili oleh merek (Ashley dan Leonard, 2009). Kepercayaan mencerminkan efek kumulatif dari waktu ke waktu pada loyalitas di pasar produk dengan tingkat keterlibatan tinggi (Chiou and Droge, 2006).

Kepercayaan merek memiliki dua dimensi yaitu niat merek (brand intention) dan kehandalan merek (brand reliability) (Delgado, 2004; Ong et al,. 2015). Niat merek merupakan keyakinan konsumen terhadap suatu merek, bahwa merek tersebut mampu mengutamakan 
kepentingan konsumen ketika masalah akibat konsumsi produk muncul secara tidak terduga (Ballester, 2004). Dengan kata lain merek yang dapat dipercaya adalah merek yang secara konsisten menjaga janjinya untuk memberi nilai kepada konsumen melalui cara produk dikembangkan, diproduksi, dijual, diservis dan diiklankan, dan bahkan di saat-saat buruk ketika beberapa jenis krisis merek muncul (Delgado et al., 2003; Morgan dan Hunt, 1994).Sedangkan kehandalan merek adalah keyakinan yang didasarkan pada sejauh mana konsumen percaya bahwa produk tersebut mampu memenuhi nilai dan dan kebutuhan yang dijanjikan (Delgado, 2004). Lebih lanjut, konsumen, mengembangkan kepercayaan pada merek berdasarkan keyakinan positif mengenai harapan mereka terhadap perilaku organisasi dan kinerja produk yang diwakili oleh merek (Ashley dan Leonard, 2009).

Sebagian peneliti melakukan pengukuran kepercayaan merek menggunakan kedua dimensinya secara terpisah (Delgado, 2004; Ong et al,. 2015; Halim, 2006). Namun ada juga peneliti yang mengukur kepercayaan merek tanpa memisahkan dimensi kehandalan merek dan niat merek (Dastan, I., \& Gecti, F. (2014); Afif et al., 2015; Gecti\& Zengin, 2011). Perbedaan pengukuran tersebut tidak mengurangi validitas hasil pengukuran, karena indikator yang diukur secara keseluruhan adalah sama. Sehingga perbedaan tersebut tidak perlu diperdebatkan.

\section{Brand Affect}

Pengertian dari brand affect adalah perasaan positif yang timbul karena penggunaan atau konsumsi merek oleh konsumen ( Chauduri \& Holbrook, 2001). Dari pengertian tersebut dapat diartikan bahwa konsumen memiliki potensi mendapatkan respon emosional positif yang dirasakan setelah penggunaan merek. Brand affect dapat dipandang sebagai evaluasi keseluruhan merek yang menguntungkan atau tidak menguntungkan bagi konsumen (Keller, 1993; Bhat \& Reddy, 2001).Affect merupakan reaksi psikologis (emosi atau perasaan) berupa kesenangan, kemarahan, kesedihan dan kegembiraan. Sedangkan dalam manajemen merek Brandaffect adalah perasaan positif atau negatif yang dirasakan oleh konsumen tentang merek yang mencakup nama, logo, atau slogan (Moorman et al., 1992).

Morgan dan Hunt (1994) mendefinisikan brand affectsebagai respon emosional positif yang diperoleh dari merek. Dengan kata lain,brand affect adalah perasaan yang menggairahkan, optimis dan memuaskan saat konsumen menggunakan produk dari suatu merek. Studi telah menemukan efek positif dari pengaruh merek terhadap kognisi konsumen dan perilaku. Brand affectpositif berarti konsumen memiliki kesan dan perasaan yang baik dan akan meningkatkan evaluasi merek di benak konsumen. Sebaliknya, jika konsumen memiliki perasaan negatif terhadap merek maka akan mempengaruhi respon, dan mereka akan merasa tidak puas dengan merek tertentu sehingga evaluasi merek akan sangat rendah. Sejalan dengan pendapat tersebut Russell (1991) mengemukakan bahwa penggunaan kesenangan / ketidaksenangan sebagai dua dimensi yang berbeda untuk mengukur affect. Dengan kata lain, ketika konsumen menggunakan produk, mereka akan merasakan perasaan senang atau tidak senang, kemudian mengevaluasi merek secara lebih jauh dengan mengungkapkan perasaan mereka akibat penggunaan merek.

\section{Kepercayaan Merek sebagai Anteseden Loyalitas Merek}

Dalam literatur pemasaran dan perilaku konsumen, kepercayaan merek telah diyakini merupakan anteseden dari loyalitas merek (Matzler 2006; Matzler, et al, 2008; Sung et al, 2010; Ming et al, 2011, Ong et al., 2015). Baik akademisi maupun praktisi mengakui pentingnya membangun dan mengembangkan kepercayaan merek untuk meningkatkan loyalitas pelanggan karena mereka menganggap kepercayaan sebagai inti dari nilai yang diberikan oleh merek yang kuat kepada konsumen. Matzler (2006) menyatakan bahwa kepercayaan merek berperan penting dalam meningkatkan dimensi loyalitas merek yaitu loyalitas sikap dan loyalitas pembelian.

Kepercayaan merek dan loyalitas merek merupakan konsep yang sangat penting dalam pengelolaan merek (Chauduri \& Holbrook, 2001). Kepercayaan merek memberikan pengaruh terbesar dalam pembentukan loyalitas merek (Taylor et al., 2004). Variabel kepercayaan merek merupakan paling penting dalam mengembangkan hubungan dengan pelanggan dalam jangka panjang seperti loyalitas merek (Delgado\&Manuera, 2001).Kepercayaan sangat penting dalam membangun hubungan konsumen dengan suatu merek yang kuat (Fournier, 1998; Urban, Sultan, and Qualls, 2000), dan berhubungan positif dengan loyalitas merek (Lau dan Lee, 1999). 
Berdasarkan berbagai pendapat tersebut maka kepercayaan merek secara meyakinkan merupakan anteseden dari loyalitas merek.

\section{Brand affectsebagai Anteseden Loyalitas Merek}

Affect adalah sekumpulan emosi, suasana hati (mood) dan sikap (Bagozzi et al., 1999). Sedangkan brand affect didefiniskan sebagai potensi merek untuk menghasilkan respon emosional positif pada konsumen rata-rata sebagai akibat penggunaannya(Chaudhuri dan Holbrook, 2001). Emosional positif tersebut biasanya terkait dengan pengalaman individu tentang produk dan jasa.Brand affect berperan penting meningkatkan perilaku pembelianyaitu loyalitas sikap dan loyalitas pembelian (Lin \& Lee, 2012). Hal tersebut menunjukan bahwa loyalitas merek tidak sekadar pembelian yang berulang-ulang, namun juga mencakup preferensi sikap terhadap merek(Wheeler\& Tomala, 2003). Oleh karena itu, ketika konsumen online merasakan emosi positif dan memiliki ikatan afektif dengan situs web, mereka akan lebih rela menjalin hubungan jangka panjang (loyal) dengan situs web (Lin \& Lee, 2012).Brand affect secara signifikan dapat meningkatkan loyalitas sikap (Gecti\& Zengin, 2013). Brand affect memiliki hubungan positif dengan loyalitas merek (Anwar et al. 2011). Dari uraian tersebut dapat diketahui bahwa brand affect merupakan faktor penentu dari loyalitas merek.

Hubungan antara kepercayaan merek dan brand affect dengan loyalitas merek, diringkas dalam gambar berikut.

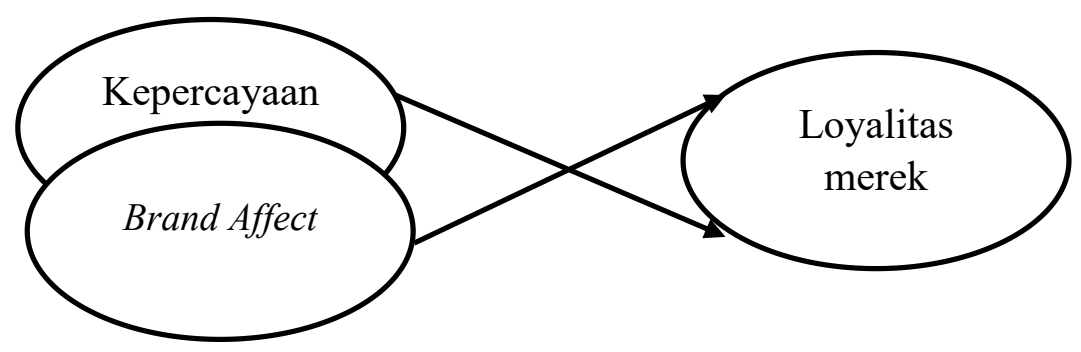

Gambar.1 Hubungan Antara Kepercayaan Merek, Brand Affect Dengan Loyalitas Merek Sumber : Gectic \& Zengin, (2013); Matzler, (2006); Ong et al., (2015)

\section{PENUTUP}

Merek tidak hanya sekedar nama atau simbol namun lebih luas merek memiliki peran sebagai pembeda dari merek pesaing, dan menjadi faktor penentu keunggulan bersaing perusahaan.Oleh karena itu perusahaan dan pemasar harus berupaya menciptakan, merawat, melindungi dan meningkatkan kualitas merek.

Loyalitas merek merupakan komponen penting dalam manajemen pemasaran, karena loyalitas banyak memberikan manfaat bagi perusahaan. Manfaat loyalitas merek adalah dapat memberikan kontribusi dan manfaat penting bagi kelangsungan hidup perusahaan, dan dapat mengurangi biaya pemasaran. Loyalitas merek merupakan inti dari setiap nilai merek. Pada saat inti dari setiap nilai merek tersebut didapatkan dan dipertahankan, loyalitas terhadap sebuah produk barang atau jasa akan bertahan lama, sehingga membuat pelanggan enggan untuk berpindah ke merek lain. Hal tersebut akan memberikan keuntungan bagi merek perusahaan. Oleh karena itu, suatu perusahaan harus mampu membangun dan mempertahankan loyalitas merek agar dapat menjaga keberlangsungan hidup perusahaan.

Loyalitas merek harus diukur menggunakan dua dimensi yaitu behavioral dan attitudinal. Karena jika hanya diukur menggunakan satu dimensi perilaku saja, dianggap konsep yang masih lemah dan tidak mampu menjelaskan loyalitas merek yang sesungguhnya. Oleh karena itu beberapa peneliti mengembangkan loyalitas merek dan menggunakan dua dimensi dalam setiap pengukurannya.

Kepercayaan merek melalui dua komponennya yaitu niat merek dan kehandalan merek memainkan peran penting dalam upaya membangun loyalitas merek. Hal tersebut dikarenakan 
kepercayaan merek adalah inti dari nilai yang diberikan oleh merek kuat kepada pelanggan. Konsumen yang memiliki kepercayaan merek berperan dalam meningkatkan niat membeli kembali secara berulang-ulang, kemudian merekomendasikan kepada orang lain dan bersedia membayar harga premium. Oleh karena itu tanpa adanya kepercayaan terhadap merek maka loyalitas tidak akan tercapai.

Brand affect diyakini menjadi penentu terciptanya loyalitas merek. Karena konsumen akan memutuskan setia kepada merek tergantung dari perasaan yang dirasakan setelah mengkonsumsi suatu merek. Perasaan tersebut berupa perasaan positif atau negatif. Jika konsumen memiliki pengalaman positif dalam penggunaan merek, maka konsumen akan melanjutkan pembeliannya pada merek yang sama dalam jangka panjang. Namun sebaliknya apabila konsumen merasakan perasaan negatif, misalnya kecewa maka konsumen akan mengkahiri konsumsinya terhadap merek tersebut.

Dari penjelasan tersebut, maka dapat disimpulkan bahwa kepercayaan merek dan brand affect memiliki peran sangat penting dalam upaya membangun dan memelihara loyalitas merek. Oleh karena itu baik kepercayaan merek maupum brand affect secara meyakinkan dapat dinyatakan sebagai anteseden dari loyalitas merek.

\section{DAFTAR PUSTAKA}

Aaker, D. (1991). Brand equity. La gestione del valore della marca, 347-356.

Aaker, J. L. (1997). Dimensions of brand personality. Journal of marketing research, 347-356.

Afif, N. C., Sutiksno, D. U., Hardiyanto, N., \& Shiratina, A. (2015). Building brand loyalty through increasing brand trust and brand affect. International Journal of Scientific \& Technology Research, 4(11), 336-340.

Anwar, A., Gulzar, A., Sohail, F. B., \& Akram, S. N. (2011). Impact of brand image, trust and affect on consumer brand extension attitude: the mediating role of brand loyalty. International Journal of Economics and Management Sciences, 1(5), 73-79.

Ashley, C., \& Leonard, H. A. (2009). Betrayed by the buzz? Covert content and consumer-brand relationships. Journal of Public Policy \& Marketing, 28(2), 212-220.

Bagozzi, R. P., Gopinath, M., \& Nyer, P. U. (1999). The role of emotions in marketing. Journal of the academy of marketing science, 27(2), 184-206.

Bhat, S., \& Reddy, S. K. (2001). The impact of parent brand attribute associations and affect on brand extension evaluation. Journal of Business Research, 53(3), 111-122.

Bowen, J. T., \& Chen, S. L. (2001). The relationship between customer loyalty and customer satisfaction. International journal of contemporary hospitality management, 13(5), 213217.

Chang, N. J., \& Fong, C. M. (2010). Green product quality, green corporate image, green customer satisfaction, and green customer loyalty. African Journal of Business Management, 4(13), 2836.

Chaudhuri, A., \& Holbrook, M. B. (2001). The chain of effects from brand trust and brand affect to brand performance: the role of brand loyalty. Journal of marketing, 65(2), 81-93.

Chiou, J. S., \& Droge, C. (2006). Service quality, trust, specific asset investment, and expertise: Direct and indirect effects in a satisfaction-loyalty framework. Journal of the academy of marketing science, 34(4), 613-627.

Day, G. S. (1976). A two-dimensional concept of brand loyalty. In Mathematical models in marketing (pp. 89-89). Springer, Berlin, Heidelberg.

Dastan, I., \& Gecti, F. (2014). Relationships among utilitarian and hedonic values, brand affect and brand trust in the smartphone industry. Journal of Management Research, 6(2), 124.

Delgado-Ballester, E., \& Luis Munuera-Alemán, J. (2001). Brand trust in the context of consumer loyalty. European Journal of marketing, 35(11/12), 1238-1258.

Delgado-Ballester, E., Munuera-Aleman, J. L., \& Yague-Guillen, M. J. (2003). Development and validation of a brand trust scale. International Journal of Market Research, 45(1), 35-54.

Delgado-Ballester, E. (2004). Applicability of a brand trust scale across product categories: A multigroup invariance analysis. European Journal of Marketing, 38(5/6), 573-592.

Fournier, S. (1998). Consumers and their brands: Developing relationship theory in consumer research. Journal of consumer research, 24(4), 343-373. 
Gecti, F., \& Zengin, H. (2013). The relationship between brand trust, brand affect, attitudinal loyalty and behavioral loyalty: A field study towards sports shoe consumers in Turkey. International Journal of Marketing Studies, 5(2), 111.

Halim, R. E. (2006). The effect of the relationship of brand trust and brand affect on brand performance: An analysis from brand loyalty perspective (A case of instant

Jacoby, J., \& Chestnut, R. W. (1978). Brand loyalty. Wiley.

Keller, K. L. (1993). Conceptualizing, measuring, and managing customer-based brand equity. the Journal of Marketing, 1-22.

Lau, G. T., \& Lee, S. H. (1999). Consumers' trust in a brand and the link to brand loyalty. Journal of Market-Focused Management, 4(4), 341-370.

Lin, M. Q., \& Lee, B. C. (2012). The influence of website environment on brand loyalty: brand trust and brand affect as mediators. International Journal of Electronic Business Management, 10(4), 308.

Matzler, K., Grabner-Kräuter, S., \& Bidmon, S. (2008). Risk aversion and brand loyalty: the mediating role of brand trust and brand affect. Journal of Product \& Brand Management, 17(3), 154-162.

Ming, T. T., Ismail, H. B., \& Rasiah, D. (2011). Hierarchical chain of consumer-based brand equity: Review from the fast food industry. The International Business \& Economics Research Journal, 10(9), 67.

Morgan, R. M., \& Hunt, S. D. (1994). The commitment-trust theory of relationship marketing. The journal of marketing, 20-38.

Mooradian, T., Renzl, B., \& Matzler, K. (2006). Who trusts? Personality, trust and knowledge sharing. Management learning, 37(4), 523-540.

Moorman, C., Zaltman, G., \& Deshpande, R. (1992). Relationships between providers and users of market research: The dynamics of trust within and between organizations. Journal of marketing research, 29(3), 314.

Oliver, R. L. (1999). Whence consumer loyalty? the Journal of Marketing, 33-44.

Ong, C. H., \& Zien Yusoff, R. (2015). Influence of Brand Experience and Personality on Loyalty Dimensions: Evidence from Successful Malaysian SME Brands.

Petty, R. E., Wheeler, S. C., \& Tormala, Z. L. (2003). Persuasion and attitude change. Handbook of psychology.

Rangkuti, F. (2004). Flexible Marketing. Gramedia Pustaka Utama.

Russell, J. A. (1991). Culture and the categorization of emotions. Psychological bulletin, 110(3), 426.

Sung, Y., \& Kim, J. (2010). Effects of brand personality on brand trust and brand affect. Psychology \& Marketing, 27(7), 639-661.

Taylor, F. W. (2004). The purchasing power parity debate. Scientific management. Routledge.

Urban, G. L., Sultan, F., \& Qualls, W. J. (2000). Placing trust at the center of your Internet strategy. MIT Sloan Management Review, 42(1), 39.

Wang, G. (2002). Attitudinal correlates of brand commitment: an empirical study. Journal of Relationship Marketing, 1(2), 57-75.

Wang, F., \& Head, M. (2007). How can the web help build customer relationships?: an empirical study on e-tailing. Information \& Management, 44(2), 115-129. 


\title{
KEPERCAYAAN MEREK DAN BRAND AFFECT SEBAGAI ANTESEDEN DARI LOYALITAS MEREK
}

\author{
Sri Rahayu \\ Mahasiswa Program Doktor Ilmu Ekonomi (PDIE), Universitas Sebelas Maret Surakarta \\ Email: rahayu_ms@yahoo.com
}

Mugi Harsono

Universitas Sebelas Maret Surakarta

Email: mugihs@uns.ac.id

\begin{abstract}
The purpose of this paper is to explain the important role of brand and brand loyalty in marketing activities. This paper also explains the antecedents of brand loyalty. The role of a brand does not only actas a name, but also increasing the company's competitive advantage. The benefits of a brand for consumers are, among many others, for emotional, self and social expression, attitudes, values and culture benefits. In the mean time, the role of brand loyalty in marketing is to contribute to the survival of the company, to increase new customer opportunities as well as to reduce marketing costs. To improve a brand loyalty, a companyshould increase its brand trust in advance as it plays an important role in improving brand loyalty. A cpmpany brand trust has two dimensions of intention and reliability. Brand affect, on the other hand, is an important for improving a brand loyalty. Therefore, a company'sbrand trust and brand affect should be improved for the brand loyalty to improve as well.
\end{abstract}

Key words : Brand trust, Brand Affect, Brand Loyalty

\begin{abstract}
Abstrak
Tujuan makalah ini adalah untuk menjelaskan mengenai peran pentingmerek dan loyalitas merek dalam aktifitas pemasaran. Tujuan lainnya untuk menjelaskan anteseden dari loyalitas merek. Merek tidak hanya berperan sebagai nama, namun lebih dari itu dapat meningkatkan keunggulan kompetitif perusahaan. Sedangkan manfaat merek bagi konsumen adalah manfaatemosional, ekspresidiridan social, atibut, nilai dan kebudayaan. Peran loyalitas dalam pemasaran adalah mampu berkontribusi bagi kelangsunganhidupperusahaan, membukapeluangpelangganbarudandapatmengurangibiayapemasaran. Untuk meningkatkan loyalitas merek, harus meningkatkan kepercayaan merek terlebih dahulu. Karena kepercayaan merek memaninkan peran penting dalam upaya meningkatkan loyalitas merek.Kepercayaan merek memiliki dua dimensi yaitu intention dan reliabilitydari sebuah merek. Brand affect, merupakan faktor penting yang sangat dibutuhkan dalam meningkatkan loyalitas merek. Oleh karena itu,dalam meningkatkan loyalitas merek, sebuah perusahaan harus meningkatkan kepercayaan dan brand affect.
\end{abstract}

Kata Kunci: kepercayaan merek, pengaruh merek, loyalitas merek

\section{PENDAHULUAN}

Dewasa ini persaingan usaha dibidang industri barang maupun jasa semakin kompetitif. Adanya persaingan tersebut memaksa setiap perusahaan berupaya mencari strategi yang tepat untuk mempertahankan kelangsungan hidup perusahaan dan memenangkan persaingan. Upaya yang dapat dilakukan oleh perusahaan adalah mempertahankan pelanggan melalui merek.Merek adalah nama, istilah, tanda, simbol, desain atau kombinasi dari semuanya yang berguna untuk mengidentifikasi produk para penjual dan membedakan dari produk pesaing (Lamb, 2001). Peranan merek bukan lagi sekedar nama ataupun pembeda dari merek pesaing, lebih dari itu, 
merek sudah menjadi faktor penentu keunggulan bersaing. Aaker (1997) menjelaskan bahwa sebuah merek bisa memiliki posisi yang sangat kuat dalam menjaga loyalitas konsumen.

Menjaga loyalitas ini menjadi alasan penting bagi sebuah perusahaan untuk mengelola dan mengembangkan merek agar lebih bermakna daripada sekedar produk. Produk hanya menjelaskan atribut dimensinya yang akan dipertukarkan dan mudah ditiru oleh perusahaan lain, sedangkan merek dapat menjelaskan emosi serta hubungan secara spesifik dengan pelanggan serta sifatnya tidak berwujud (intangible) sehingga tidak mudah ditiru oleh pesaing. Merek berusaha untuk selalu menumbuhkan loyalitas. Menurut Rangkuti (2004) apabila para konsumen beranggapan bahwa merek tertentu secara fisik berbeda dari merek pesaing, citra merek tersebut akan melekat secara terus-menerus sehingga dapat membentuk kesetiaan terhadap merek tertentu yang pada akhirnya akan menciptakan loyalitas pelanggan.

Merek suatu produk atau jasa dianggap memiliki jiwa, sehingga dapat dipandang sebagai suatu organisasi, orang, atau simbol yang berfungsi sebagai alat untuk membedakan antara produk yang satu dengan produk lainnya (Halim, 2006; Chauduri \& Holbrook, 2001). Pendapat lainya menganggap bahwa merek memiliki kekuatan yang bermanfaat bagi perusahaan antara lain; dapat mengurangi kerentanan terhadap pasar yang kompetitif, memberikan marjin yang lebih besar, membantu hubungan kerjasama dengan perusahaan lain dan menciptakan peluang untuk memperluas merek (Delgado\& Manuera, 2004). Dari penjelasan tersebut, diketahui bahwa merek merupakan sesuatu yang sangat penting bagi suatu perusahaan dalam menjalankan aktivitas pemasaran produk dan jasa.

Dalam literatur manajemen pemasaran, loyalitas merek atau brand loyalty dianggap sebagai sebuah konsep yang sangat penting. Hal ini dikarenakan brand loyalty merupakan inti dari setiap nilai merek. Pada saat inti dari setiap nilai merek tersebut didapatkan dan dipertahankan, loyalitas terhadap sebuah produk barang atau jasa akan bertahan lama. Hal tersebut menyebabkan pelanggan enggan untuk berpindah ke merek lain dan akan memberikan keuntungan bagi merek perusahaan (Aaker, 1997; Baldinger \& Rubinson, 1996; Chaudhuri, 1999). Oleh karena itu, suatu perusahaan harus mampu membangun dan mempertahankan loyalitas merek agar dapat menjaga keberlangsungan hidup perusahaan.

Beberapa penelitian terdahulu telah banyak membahas mengenai peran kepercayaan merek, brand affect, dan kepuasan merek dalam meningkatkan loyalitas merek. Seperti penelitian yang dilakukan oleh Kuo (2012) Brand affect dapat berperan dalam meningkatkan loyalitas merek (Kuo, 2012). Brand affect dan kepercayaan merek berpengaruh positif terhadap loyalitas merek (Anwar, et al., 2011, Ong et al., 2015, Gecti\& Zengin, 2013; Kurt Matzler, 2006).Dari penjelasan tersebut, maka diketahui bahwa loyalitas merek dapat ditingkatkan dengan meningkatkan kepercayaan merek, dan brand affect.

Artikel ini bertujuan untuk menjelaskan peran penting dari variabel loyalitas merek dalam kegiatan pemasaran. Selain itu untuk menjelaskan aktor penentu atau anteseden dari loyalitas merek. Faktor tersebut meliputi kepercayaan merek dan brand affect. Penjelasan tersebut akan disajikan pada bagian pembahasan.

\section{PEMBAHASAN}

\section{Merek}

Merek adalah nama, istilah, tanda, simbol, desain atau kombinasi dari semuanya yang berguna untuk mengidentifikasi produk para penjual dan membedakan dari produk pesaing (Lamb, 2001). Peranan merek bukan lagi sekedar nama ataupun pembeda dari merek pesaing, lebih dari itu, merek sudah menjadi faktor penentu keunggulan bersaing.Selain itu merek merek merupakan sebuah janji dari suatu organisasi kepada pelanggan untuk memberikan manfaat yang ditawarkan oleh merek tersebut. Manfaat yang diberikan tidak hanya manfaat fungsional saja, namun meliputi manfaat emosional, ekspresi diri dan sosial (Aaker, 2015). Lebih jauh merek dianggap sebagai kumpulan dari atribut, manfaat, nilai, dan kebudayaan (Kotler, 2005). Berdasarkan penjelasan tersebut maka dapat diketahui peranan merek tidak hanya sekedar nama atau simbol, namun lebih jauh merek mampu berperan menjadi keunggulan bersaing perusahaan, manfaar emosional, ekspresi diri konsumen, dan manfaat sosial. Selain itu merek juga merupakan atribut, nilai dan 
kebudayaan. Oleh karena itu suatu perusahaan harus berupaya keras untuk menciptakan, memelihara, melindungi dan meningkatkan kualitas merek.

\section{Loyalitas Merek}

Loyalitas merek merupakan konsep yang sangat penting dalam literatur pemasaran. Loyalitas merek dapat memberikan kontribusi dan manfaat penting bagi kelangsungan hidup perusahaan, membuka peluang pelanggan baru dan dapat mengurangi biaya pemasaran. Hal tersebut disebabkan oleh konsumen yang loyal terhadap suatu merek, akan melakukan pembelian secara berulang-ulang, bersedia membayar dengan harga premium, dan merekomendasikan kepada orang lain (Wang, 2007, Chang \& Fong, 2010). Selain dapat mengurangi biaya pemasaran loyalitas konsumen juga akan membuka peluang untuk mendapatkan konsumen baru yang dihasilkan dari rekomendasi dari pelanggan. Sebagaimana diketahui bahwa konsumen akan lebih percaya kepada orang sudah memiliki pengalaman menggunakan suatu merek dibanding dengan iklan atau promosi dari perusahaan.

Loyalitas merek didefinisikan sebagai komitmen yang sangat kuat untuk membeli kembali atau berlanganan pada produk atau jasa yang diinginkan secara konsisten di masa depan, sehingga menyebabkan pembelian merek atau barang yang sama, walaupun ada pengaruh situasional dan upaya pemasaran yang berpotensi menyebabkan perilaku beralih (Oliver, 1999). Definisi tersebut menekankan dua aspek yang berbeda yaitu konsep perilaku (behavioral) dan sikap (attitudinal) (Aaker, 1991; Day 1969; Assael, 1998; Oliver, 1999; Jacoby \& Chesnut, 1978). Loyalitas perilaku atau pembelian (behavioral and purchase) adalah pembelian merek secara berulang - ulang, sedangkan loyalitas sikap merek (attitudinal loyalty) adalah tingkat komitmen terhadap nilai-nilai unik yang terdapat pada merek.

Beberapa penelitian menggunakan istilah loyalitas pembelian (purchase loyalty) dan loyalitas sikap (attitudinal loyalty) (Chauduri \& Holbrook, 2001; Matzler, 2006). Sedangkan Gectic \& Zengin, (2013) menyebut dimensi loyalitas merek dengan istilah behavioral loyalty dan attitudinal loyalty. Seperti telah dijelaskan sebelumnya bahwa antara Behavioral loyalty dan purchase loyalty memiliki makna yang sama, yaitu perilaku konsumen dalam melakukan pembelian secara berulang-ulang.

Pengukuran loyalitas merek harus melibatkan dua dimensi yaitu behavioral dan attitudinal loyalty. Karena loyalitas tidak cukup hanya diukur dari satu sisi saja, misal perilaku pembelian yang berulang-ulang. Namun harus diukur dari loyalitas pembelian dan loyalitas sikap. Pengukuran loyalitas yang hanya menggunakan satu dimensi keperilakuan saja dilakukan oleh beberapa peneliti sebelumnya (Bowen dan Chen, 2001; Lau dan Lee, 1999). Hal tersebut bertentangan dengan pendapat yang menyatakan bahwa mengukur loyalitas merek harus melibatkan kedua dimensinya. Pengukuran loyalitas merek yang dilakukan hanya dari perilaku pembelian saja dianggaptidak mampu menjelaskan loyalitas merek dan menunjukan konsep loyalitas merek sebagai konsep yang masih lemah sehinggamembutuhkan pengembangan lebih lanjut, (Jacoby dan Chesnut, 1978). Aaeker (1991), Oliver (1999) mengembangkan pengukuran yang menekankan dua aspek yang berbeda yaitu konsep perilaku (behavioral) dan sikap (attitudinal).

\section{Kepercayaan Merek}

Kepercayaan merek didefinisikan sebagai ekspektasi keyakinanterhadap kehandalan dan niat dalam situasi yang melibatkan risiko kepada konsumen (Delgado, 2004). Definisi lain dari kepercayaan merek adalah perilaku kerelaan konsumen untuk bergantung pada kemampuan merek yang menggambarkan fungsi produk (Chauduri \& Holbrook, 2001). Melengkapi kedua definisi tersebut Wang (2002) mendefinisikan kepercayaan merek sebagai kesediaan konsumen untuk mengandalkan dan meyakini merek tersebut terkait dengan kehandalan merek, jujur dan altruisme (Wang, 2002). Konsumen, mengembangkan kepercayaan pada merek berdasarkan keyakinan positif mengenai ekspektasi mereka terhadap perilaku organisasi dan kinerja produk yang diwakili oleh merek (Ashley dan Leonard, 2009). Kepercayaan mencerminkan efek kumulatif dari waktu ke waktu pada loyalitas di pasar produk dengan tingkat keterlibatan tinggi (Chiou and Droge, 2006).

Kepercayaan merek memiliki dua dimensi yaitu niat merek (brand intention) dan kehandalan merek (brand reliability) (Delgado, 2004; Ong et al,. 2015). Niat merek merupakan keyakinan konsumen terhadap suatu merek, bahwa merek tersebut mampu mengutamakan 
kepentingan konsumen ketika masalah akibat konsumsi produk muncul secara tidak terduga (Ballester, 2004). Dengan kata lain merek yang dapat dipercaya adalah merek yang secara konsisten menjaga janjinya untuk memberi nilai kepada konsumen melalui cara produk dikembangkan, diproduksi, dijual, diservis dan diiklankan, dan bahkan di saat-saat buruk ketika beberapa jenis krisis merek muncul (Delgado et al., 2003; Morgan dan Hunt, 1994).Sedangkan kehandalan merek adalah keyakinan yang didasarkan pada sejauh mana konsumen percaya bahwa produk tersebut mampu memenuhi nilai dan dan kebutuhan yang dijanjikan (Delgado, 2004). Lebih lanjut, konsumen, mengembangkan kepercayaan pada merek berdasarkan keyakinan positif mengenai harapan mereka terhadap perilaku organisasi dan kinerja produk yang diwakili oleh merek (Ashley dan Leonard, 2009).

Sebagian peneliti melakukan pengukuran kepercayaan merek menggunakan kedua dimensinya secara terpisah (Delgado, 2004; Ong et al,. 2015; Halim, 2006). Namun ada juga peneliti yang mengukur kepercayaan merek tanpa memisahkan dimensi kehandalan merek dan niat merek (Dastan, I., \& Gecti, F. (2014); Afif et al., 2015; Gecti\& Zengin, 2011). Perbedaan pengukuran tersebut tidak mengurangi validitas hasil pengukuran, karena indikator yang diukur secara keseluruhan adalah sama. Sehingga perbedaan tersebut tidak perlu diperdebatkan.

\section{Brand Affect}

Pengertian dari brand affect adalah perasaan positif yang timbul karena penggunaan atau konsumsi merek oleh konsumen ( Chauduri \& Holbrook, 2001). Dari pengertian tersebut dapat diartikan bahwa konsumen memiliki potensi mendapatkan respon emosional positif yang dirasakan setelah penggunaan merek. Brand affect dapat dipandang sebagai evaluasi keseluruhan merek yang menguntungkan atau tidak menguntungkan bagi konsumen (Keller, 1993; Bhat \& Reddy, 2001).Affect merupakan reaksi psikologis (emosi atau perasaan) berupa kesenangan, kemarahan, kesedihan dan kegembiraan. Sedangkan dalam manajemen merek Brandaffect adalah perasaan positif atau negatif yang dirasakan oleh konsumen tentang merek yang mencakup nama, logo, atau slogan (Moorman et al., 1992).

Morgan dan Hunt (1994) mendefinisikan brand affectsebagai respon emosional positif yang diperoleh dari merek. Dengan kata lain,brand affect adalah perasaan yang menggairahkan, optimis dan memuaskan saat konsumen menggunakan produk dari suatu merek. Studi telah menemukan efek positif dari pengaruh merek terhadap kognisi konsumen dan perilaku. Brand affectpositif berarti konsumen memiliki kesan dan perasaan yang baik dan akan meningkatkan evaluasi merek di benak konsumen. Sebaliknya, jika konsumen memiliki perasaan negatif terhadap merek maka akan mempengaruhi respon, dan mereka akan merasa tidak puas dengan merek tertentu sehingga evaluasi merek akan sangat rendah. Sejalan dengan pendapat tersebut Russell (1991) mengemukakan bahwa penggunaan kesenangan / ketidaksenangan sebagai dua dimensi yang berbeda untuk mengukur affect. Dengan kata lain, ketika konsumen menggunakan produk, mereka akan merasakan perasaan senang atau tidak senang, kemudian mengevaluasi merek secara lebih jauh dengan mengungkapkan perasaan mereka akibat penggunaan merek.

\section{Kepercayaan Merek sebagai Anteseden Loyalitas Merek}

Dalam literatur pemasaran dan perilaku konsumen, kepercayaan merek telah diyakini merupakan anteseden dari loyalitas merek (Matzler 2006; Matzler, et al, 2008; Sung et al, 2010; Ming et al, 2011, Ong et al., 2015). Baik akademisi maupun praktisi mengakui pentingnya membangun dan mengembangkan kepercayaan merek untuk meningkatkan loyalitas pelanggan karena mereka menganggap kepercayaan sebagai inti dari nilai yang diberikan oleh merek yang kuat kepada konsumen. Matzler (2006) menyatakan bahwa kepercayaan merek berperan penting dalam meningkatkan dimensi loyalitas merek yaitu loyalitas sikap dan loyalitas pembelian.

Kepercayaan merek dan loyalitas merek merupakan konsep yang sangat penting dalam pengelolaan merek (Chauduri \& Holbrook, 2001). Kepercayaan merek memberikan pengaruh terbesar dalam pembentukan loyalitas merek (Taylor et al., 2004). Variabel kepercayaan merek merupakan paling penting dalam mengembangkan hubungan dengan pelanggan dalam jangka panjang seperti loyalitas merek (Delgado\&Manuera, 2001).Kepercayaan sangat penting dalam membangun hubungan konsumen dengan suatu merek yang kuat (Fournier, 1998; Urban, Sultan, and Qualls, 2000), dan berhubungan positif dengan loyalitas merek (Lau dan Lee, 1999). 
Berdasarkan berbagai pendapat tersebut maka kepercayaan merek secara meyakinkan merupakan anteseden dari loyalitas merek.

\section{Brand affectsebagai Anteseden Loyalitas Merek}

Affect adalah sekumpulan emosi, suasana hati (mood) dan sikap (Bagozzi et al., 1999). Sedangkan brand affect didefiniskan sebagai potensi merek untuk menghasilkan respon emosional positif pada konsumen rata-rata sebagai akibat penggunaannya(Chaudhuri dan Holbrook, 2001). Emosional positif tersebut biasanya terkait dengan pengalaman individu tentang produk dan jasa.Brand affect berperan penting meningkatkan perilaku pembelianyaitu loyalitas sikap dan loyalitas pembelian (Lin \& Lee, 2012). Hal tersebut menunjukan bahwa loyalitas merek tidak sekadar pembelian yang berulang-ulang, namun juga mencakup preferensi sikap terhadap merek(Wheeler\& Tomala, 2003). Oleh karena itu, ketika konsumen online merasakan emosi positif dan memiliki ikatan afektif dengan situs web, mereka akan lebih rela menjalin hubungan jangka panjang (loyal) dengan situs web (Lin \& Lee, 2012).Brand affect secara signifikan dapat meningkatkan loyalitas sikap (Gecti\& Zengin, 2013). Brand affect memiliki hubungan positif dengan loyalitas merek (Anwar et al. 2011). Dari uraian tersebut dapat diketahui bahwa brand affect merupakan faktor penentu dari loyalitas merek.

Hubungan antara kepercayaan merek dan brand affect dengan loyalitas merek, diringkas dalam gambar berikut.

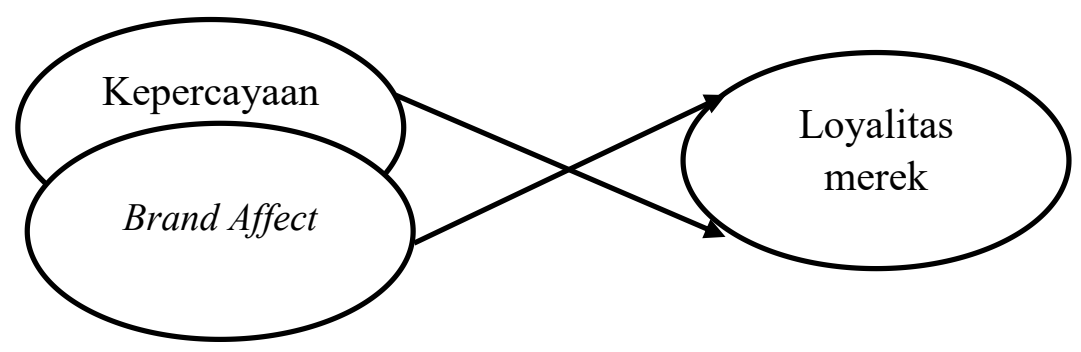

Gambar.1 Hubungan Antara Kepercayaan Merek, Brand Affect Dengan Loyalitas Merek Sumber : Gectic \& Zengin, (2013); Matzler, (2006); Ong et al., (2015)

\section{PENUTUP}

Merek tidak hanya sekedar nama atau simbol namun lebih luas merek memiliki peran sebagai pembeda dari merek pesaing, dan menjadi faktor penentu keunggulan bersaing perusahaan.Oleh karena itu perusahaan dan pemasar harus berupaya menciptakan, merawat, melindungi dan meningkatkan kualitas merek.

Loyalitas merek merupakan komponen penting dalam manajemen pemasaran, karena loyalitas banyak memberikan manfaat bagi perusahaan. Manfaat loyalitas merek adalah dapat memberikan kontribusi dan manfaat penting bagi kelangsungan hidup perusahaan, dan dapat mengurangi biaya pemasaran. Loyalitas merek merupakan inti dari setiap nilai merek. Pada saat inti dari setiap nilai merek tersebut didapatkan dan dipertahankan, loyalitas terhadap sebuah produk barang atau jasa akan bertahan lama, sehingga membuat pelanggan enggan untuk berpindah ke merek lain. Hal tersebut akan memberikan keuntungan bagi merek perusahaan. Oleh karena itu, suatu perusahaan harus mampu membangun dan mempertahankan loyalitas merek agar dapat menjaga keberlangsungan hidup perusahaan.

Loyalitas merek harus diukur menggunakan dua dimensi yaitu behavioral dan attitudinal. Karena jika hanya diukur menggunakan satu dimensi perilaku saja, dianggap konsep yang masih lemah dan tidak mampu menjelaskan loyalitas merek yang sesungguhnya. Oleh karena itu beberapa peneliti mengembangkan loyalitas merek dan menggunakan dua dimensi dalam setiap pengukurannya.

Kepercayaan merek melalui dua komponennya yaitu niat merek dan kehandalan merek memainkan peran penting dalam upaya membangun loyalitas merek. Hal tersebut dikarenakan 
kepercayaan merek adalah inti dari nilai yang diberikan oleh merek kuat kepada pelanggan. Konsumen yang memiliki kepercayaan merek berperan dalam meningkatkan niat membeli kembali secara berulang-ulang, kemudian merekomendasikan kepada orang lain dan bersedia membayar harga premium. Oleh karena itu tanpa adanya kepercayaan terhadap merek maka loyalitas tidak akan tercapai.

Brand affect diyakini menjadi penentu terciptanya loyalitas merek. Karena konsumen akan memutuskan setia kepada merek tergantung dari perasaan yang dirasakan setelah mengkonsumsi suatu merek. Perasaan tersebut berupa perasaan positif atau negatif. Jika konsumen memiliki pengalaman positif dalam penggunaan merek, maka konsumen akan melanjutkan pembeliannya pada merek yang sama dalam jangka panjang. Namun sebaliknya apabila konsumen merasakan perasaan negatif, misalnya kecewa maka konsumen akan mengkahiri konsumsinya terhadap merek tersebut.

Dari penjelasan tersebut, maka dapat disimpulkan bahwa kepercayaan merek dan brand affect memiliki peran sangat penting dalam upaya membangun dan memelihara loyalitas merek. Oleh karena itu baik kepercayaan merek maupum brand affect secara meyakinkan dapat dinyatakan sebagai anteseden dari loyalitas merek.

\section{DAFTAR PUSTAKA}

Aaker, D. (1991). Brand equity. La gestione del valore della marca, 347-356.

Aaker, J. L. (1997). Dimensions of brand personality. Journal of marketing research, 347-356.

Afif, N. C., Sutiksno, D. U., Hardiyanto, N., \& Shiratina, A. (2015). Building brand loyalty through increasing brand trust and brand affect. International Journal of Scientific \& Technology Research, 4(11), 336-340.

Anwar, A., Gulzar, A., Sohail, F. B., \& Akram, S. N. (2011). Impact of brand image, trust and affect on consumer brand extension attitude: the mediating role of brand loyalty. International Journal of Economics and Management Sciences, 1(5), 73-79.

Ashley, C., \& Leonard, H. A. (2009). Betrayed by the buzz? Covert content and consumer-brand relationships. Journal of Public Policy \& Marketing, 28(2), 212-220.

Bagozzi, R. P., Gopinath, M., \& Nyer, P. U. (1999). The role of emotions in marketing. Journal of the academy of marketing science, 27(2), 184-206.

Bhat, S., \& Reddy, S. K. (2001). The impact of parent brand attribute associations and affect on brand extension evaluation. Journal of Business Research, 53(3), 111-122.

Bowen, J. T., \& Chen, S. L. (2001). The relationship between customer loyalty and customer satisfaction. International journal of contemporary hospitality management, 13(5), 213217.

Chang, N. J., \& Fong, C. M. (2010). Green product quality, green corporate image, green customer satisfaction, and green customer loyalty. African Journal of Business Management, 4(13), 2836.

Chaudhuri, A., \& Holbrook, M. B. (2001). The chain of effects from brand trust and brand affect to brand performance: the role of brand loyalty. Journal of marketing, 65(2), 81-93.

Chiou, J. S., \& Droge, C. (2006). Service quality, trust, specific asset investment, and expertise: Direct and indirect effects in a satisfaction-loyalty framework. Journal of the academy of marketing science, 34(4), 613-627.

Day, G. S. (1976). A two-dimensional concept of brand loyalty. In Mathematical models in marketing (pp. 89-89). Springer, Berlin, Heidelberg.

Dastan, I., \& Gecti, F. (2014). Relationships among utilitarian and hedonic values, brand affect and brand trust in the smartphone industry. Journal of Management Research, 6(2), 124.

Delgado-Ballester, E., \& Luis Munuera-Alemán, J. (2001). Brand trust in the context of consumer loyalty. European Journal of marketing, 35(11/12), 1238-1258.

Delgado-Ballester, E., Munuera-Aleman, J. L., \& Yague-Guillen, M. J. (2003). Development and validation of a brand trust scale. International Journal of Market Research, 45(1), 35-54.

Delgado-Ballester, E. (2004). Applicability of a brand trust scale across product categories: A multigroup invariance analysis. European Journal of Marketing, 38(5/6), 573-592.

Fournier, S. (1998). Consumers and their brands: Developing relationship theory in consumer research. Journal of consumer research, 24(4), 343-373. 
Gecti, F., \& Zengin, H. (2013). The relationship between brand trust, brand affect, attitudinal loyalty and behavioral loyalty: A field study towards sports shoe consumers in Turkey. International Journal of Marketing Studies, 5(2), 111.

Halim, R. E. (2006). The effect of the relationship of brand trust and brand affect on brand performance: An analysis from brand loyalty perspective (A case of instant

Jacoby, J., \& Chestnut, R. W. (1978). Brand loyalty. Wiley.

Keller, K. L. (1993). Conceptualizing, measuring, and managing customer-based brand equity. the Journal of Marketing, 1-22.

Lau, G. T., \& Lee, S. H. (1999). Consumers' trust in a brand and the link to brand loyalty. Journal of Market-Focused Management, 4(4), 341-370.

Lin, M. Q., \& Lee, B. C. (2012). The influence of website environment on brand loyalty: brand trust and brand affect as mediators. International Journal of Electronic Business Management, 10(4), 308.

Matzler, K., Grabner-Kräuter, S., \& Bidmon, S. (2008). Risk aversion and brand loyalty: the mediating role of brand trust and brand affect. Journal of Product \& Brand Management, 17(3), 154-162.

Ming, T. T., Ismail, H. B., \& Rasiah, D. (2011). Hierarchical chain of consumer-based brand equity: Review from the fast food industry. The International Business \& Economics Research Journal, 10(9), 67.

Morgan, R. M., \& Hunt, S. D. (1994). The commitment-trust theory of relationship marketing. The journal of marketing, 20-38.

Mooradian, T., Renzl, B., \& Matzler, K. (2006). Who trusts? Personality, trust and knowledge sharing. Management learning, 37(4), 523-540.

Moorman, C., Zaltman, G., \& Deshpande, R. (1992). Relationships between providers and users of market research: The dynamics of trust within and between organizations. Journal of marketing research, 29(3), 314.

Oliver, R. L. (1999). Whence consumer loyalty? the Journal of Marketing, 33-44.

Ong, C. H., \& Zien Yusoff, R. (2015). Influence of Brand Experience and Personality on Loyalty Dimensions: Evidence from Successful Malaysian SME Brands.

Petty, R. E., Wheeler, S. C., \& Tormala, Z. L. (2003). Persuasion and attitude change. Handbook of psychology.

Rangkuti, F. (2004). Flexible Marketing. Gramedia Pustaka Utama.

Russell, J. A. (1991). Culture and the categorization of emotions. Psychological bulletin, 110(3), 426.

Sung, Y., \& Kim, J. (2010). Effects of brand personality on brand trust and brand affect. Psychology \& Marketing, 27(7), 639-661.

Taylor, F. W. (2004). The purchasing power parity debate. Scientific management. Routledge.

Urban, G. L., Sultan, F., \& Qualls, W. J. (2000). Placing trust at the center of your Internet strategy. MIT Sloan Management Review, 42(1), 39.

Wang, G. (2002). Attitudinal correlates of brand commitment: an empirical study. Journal of Relationship Marketing, 1(2), 57-75.

Wang, F., \& Head, M. (2007). How can the web help build customer relationships?: an empirical study on e-tailing. Information \& Management, 44(2), 115-129. 